\title{
スターリング機関用蓄熱体の性能試験*
}

（第 2 報, 各種蓄熱体の性能比較）

\author{
西本奎一*1, 稗 田、登*2
}

\section{A Study on a Performance Test of Matrices for Stirling Engines (2nd Report, Performance Comparison of Various Matrices)}

\author{
Keiichi NISHIMOTO and Noboru HIEDA
}

\begin{abstract}
The adaptability of various materials for the matrix of a Stirling engine regenerator was evaluated inclusively, considering not only their heat transfer properties which were measured and reported in the 1st report, but also their flow resistances and void volumes. Also, the assumption which was applied in the 1st report to obtain the rate of heat regeneration from the measured temperature of air was examined by numerical analysis using the finite difference method and it was found that the assumption is adequate when the rotary valve speed is more than or equal to $240 \mathrm{rpm}$. To examine the accuracy of the experiment, the heat transfer coefficients which were obtained from the air temperature were compared to those calculated by generally known empirical formulae.
\end{abstract}

Key Words: Regenerator, Stirling Engine, Heat Engine, Heat Transfer, Thermal Engineering

\section{1. 緒言}

第 1 報(1)においてはスターリング機関用の各種蓄熱 体を実際の機関の再生器に取付けてその性能を試験す る労力を軽減するために，2 個の回転弁を有する非定 常伝熱実験装置を用いて，11 種の蓄熱体の伝熱性能を 同一条件のもとにおいて測定，比較したが，機関性能 に影響をおよほす蓄熱体の性筫としては伝熱性能のほ かに, 流動抵抗, すきま体積(蓄熱体内部において作動 ガスが占める空間の体積) および熱伝導損失（蓄熱体 実質内を通過し, 高温端から低温端へ熱伝導によって 移動する熱量）などがあり，しかもこれらの性質が機 関性能におよぼす利害損失は互いに相反する場合が多 く，また作動ガスの種類や機関各部の体積比などによ って影響の程度が異なるので, 最適蓄熱体を選定する には機関諸元および運転条件を考慮する必要がある。 本報では第 1 報の実験で得られた各種蓄熱体の伝熱 性能 (熱再生率)のほかに, 流動抵抗およびすきま体積 を考虑してスターリング機関用蓄熱体としての性能を

\footnotetext{
* 平成元年 7 月 14 日 来海支部岐鼻地方講演会に扔にて請演, 原稿受付 昭和 63 年 11 月 25 日。

*1 正員, 福茾工業大学 (3910 福井市学園 3-6-1).

*2 正賁, 金沢大学工学部（事920 金沢市小立野 2-40-20).
}

総合的に比較, 評価した。なお，それに先立ち前報の解 析の際に立てた仮定の当否を吟味し, また, 熱再生率 と同じ手法で求めた熱伝達率の值を既知の実験式で求 めた值と比較し，両者の相違について考察した。供試 蓄熱体の仕様を表 1 に示す.

表 1 供試蓄熱体一覧

\begin{tabular}{|c|c|c|c|c|}
\hline Name & Symbol & size & Number & Length \\
\hline \multirow{4}{*}{$\begin{array}{l}\text { Stainless } \\
\text { Steel } \\
\text { Pipe }\end{array}$} & & I.D. & & \multirow{4}{*}{$140 \mathrm{~mm}$} \\
\hline & $P 1 \times 1.5$ & $1.5 \mathrm{~mm}$ & 449 & \\
\hline & P $1.9 \times 3$ & $1.9 \mathrm{~mm}$ & 123 & \\
\hline & P $3 \times 4$ & $3 \mathrm{~mm}$ & 62 & \\
\hline \multirow{3}{*}{$\begin{array}{l}\text { Stainless } \\
\text { Steel } \\
\text { Sphere }\end{array}$} & & Diameter & & \multirow{3}{*}{$40 \mathrm{~mm}$} \\
\hline & $S B \quad \phi 2$ & $2 \mathrm{~mm}$ & 5912 & \\
\hline & SB $\phi 3$ & $3 \mathrm{~mm}$ & 1743 & \\
\hline $\begin{array}{l}\text { Stainless } \\
\text { Mesh }\end{array}$ & $M \# 40$ & 40 mesh & 96 sheets & $40 \mathrm{~mm}$ \\
\hline \multirow{3}{*}{$\begin{array}{l}\text { Sponge } \\
\text { Metal }\end{array}$} & & Cells/inch & & \multirow{3}{*}{$40 \mathrm{~mm}$} \\
\hline & SM \#5 & $35 \sim 44$ & & \\
\hline & SM \#6 & $44 \sim 55$ & & \\
\hline \multirow{3}{*}{$\begin{array}{l}\text { Ceramic } \\
\text { Foam }\end{array}$} & & $\mathrm{Ce} 11 \mathrm{~s} / 25 \mathrm{~mm}$ & & \multirow{3}{*}{$40 \mathrm{~mm}$} \\
\hline & $C \# 20$ & $18 \sim 22$ & & \\
\hline & $c \# 30$ & $27 \sim 33$ & & \\
\hline \multirow{2}{*}{$\begin{array}{l}\text { Honeycomb } \\
\text { Ceramics }\end{array}$} & \multirow{2}{*}{ HC } & Basexhight & & \multirow{2}{*}{$140 \mathrm{~mm}$} \\
\hline & & $2 \mathrm{~mm} \times 1 \mathrm{~mm}$ & $560 \mathrm{CeI} 13$ & \\
\hline
\end{tabular}




\section{2. 熱再生率算出法の昑味}

第 1 報で述べた熱再生率算出の際の仮定は，

（1）再生器内残留空気の熱容量は蓄熱体の熱容量 に対して無視する

（2）流れ方向の蓄熱体内熱伝導は無視する

（3）流れに垂直な断面内の蓄熱体の熱拡散率は無 限大である

（4）再生器内の空気括よび蓄熱体の温度分布は直 線状で, 両者のこう配は等しい.

であるが,このうち (4)の妥当性について吟味するた めに, 各供試蓄熱体の仕様から求めた伝熱特性值を用

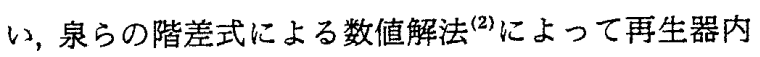
部における温度分布を試算した。

\section{基礎式住}

$$
\xi=\Lambda x / L, \quad \eta=2 \Pi t / \tau
$$

として，(特記しない記号は第 1 報に同じ）

$$
\frac{\partial T}{\partial \xi}=T_{m}-T, \quad \frac{\partial T_{m}}{\partial \eta}=T-T_{m}
$$

$r: x$ 方向分割番号 (空気入口側を 1 とする)

$s$ : 時間分割番号 $(r, s$ とも 1,2 , ,21)

$$
\alpha=\Lambda / 20, \quad \beta=\Pi / 20
$$

$A_{1}=(2-\alpha) /(2+\alpha)$

$A_{2}=\alpha /(2+\alpha), \quad B_{1}=(2-\beta) /(2+\beta)$

$B_{2}=\beta /(2+\beta), \quad K_{1}=B_{1} /\left(1-A_{2} B_{2}\right)$

$K_{2}=B_{2} /\left(1-A_{2} B_{2}\right)$

$K_{3}=A_{2} B_{2} /\left(1-A_{2} B_{2}\right)$

$K_{4}=A_{1} B_{2} /\left(1-A_{2} B_{2}\right)$

とすれば,

$$
\begin{aligned}
& T(r+1, s)=A_{1} T(r, s) \\
& \quad+A_{2}\left[T_{m}(r+1, s)+T_{m}(r, s)\right] \\
& T_{m}(1, s+1)=B_{1} T_{m}(1, s) \\
& \quad+B_{2}[T(1, s+1)+T(1, s)] \\
& T_{m}(r, s+1)=K_{1} T_{m}(r, s)+K_{2} T(r, s) \\
& \quad+K_{3} T_{m}(r-1, s+1)+K_{4} T(r-1, s+1)
\end{aligned}
$$

すなわち無次元長さ $\Lambda$ および無次元半周期 $\Pi$ をそ れぞれ 20 分割した階差式によって温度分布を求める. 境界条件：受熱期間では $T(1, s)=T_{h}$ 放熱期間では $T(1, s)=T_{c}$

初期条件：第 1 受熱期間では $T_{m}(r, 1)=T_{c}$, その後 はある受熱期間の終わりの蓄熱体温度分布の $x$ 座標 を反転したものをつぎの放熱期間の初期条件とすれば よい. 数值計算は各点の温度変化が $0.1^{\circ} \mathrm{C}$ 末満になる まで繰返した。

図 1 に空気および蓄熱体の温度分布の計算結果の一 部を示す。また第 1 報の再生器両端における測定温度
を図 3 に示す，図 3 では両端の温度を直線で結んであ るが, 図 1 によればそれがほぼ妥当であることがわか る.ただし，図 1 の M 40 の受熱および放熱期間にお ける架気の最高, 最低温度は回転速度の低い場合, 直 線からわずかに外れるが，それらの平均值は図 2 に示 すとおりほぼ直線となり，また $240 \mathrm{rpm}$ 以上ではさら に直線に近付くので，現実の機関の実用回転速度 (300 $\mathrm{rpm}$ 以上）では前述の仮定（4）が妥当であることがわ かる. 図 3 における空気温度と蓄熱体温度のこう配が 多少異なっているのは温度測定の誤差によるものと思 われる。

\section{3. 熱 伝 達 率}

第 1 報では非定常伝熱実験で求めた蓄熱体両端にお ける空気温度の測定值から熱再生率を求めたが, 同様 にして, 熱伝達率 $h$ は次式で求めることができる。

$$
h=\frac{\dot{m} c_{p} \Lambda}{s}=\frac{2 \dot{m} c_{p}}{s} \frac{1-F}{F-\frac{\dot{m} c_{p} \tau}{4 M C}}
$$

この式で求められる熱伝達率の值は第 1 報で述べた仮 定に基づくものであって，これを総括熱伝達率と呼ぶ ことにする.（式中の記号は第 1 報に同じ）

一方, 各蓄熱体の形状, 寸法, 物性值扔よび空気流 速にもとづいて熱伝達率を既知の実験式によって算出 し, 空気温度測定結果を式 (1)に代入して求めた值と 比較, 対照してみることとする.

ステンレスパイプおよびステンレス鋼球の熱伝達率 算定には日本機械学会伝熱工学資料 ${ }^{(3)}$ の式を，またス テンレス金網および発泡金属には浜口, 宮部の式(4),(5) を用いた．ゼラミックフォームは，材質は異なるけれ ども幾何学的構造は発泡金属と同一なので，発泡金属 と同じ式を使用した。八ニカムセラミックスに対して は，三角形通路の水力平均深さの 4 倍を直径とみなし てステンレスパイプと同じ円管の式を用いた。

それらの式を以下に示す.

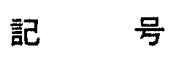

$$
\begin{aligned}
C & : \text { 蓄熱体の比熱 } \\
c_{\rho} & : \text { 空気の比熱 } \\
d & : \text { 直径 } \\
d_{m} & : \text { 発泡体の平均壁厚 } \\
E & : \text { 熱再生率 } \\
h & : \text { 熱伝達率 } \\
L & : \text { 蓄熱体全長 } \\
M & : \text { 蓄熱体の質量 } \\
\dot{m} & : \text { 空気の質量流量 }
\end{aligned}
$$


$\mathrm{Nu}$ : ヌセルト数

$\operatorname{Pr}:$ プラントル数

$p:$ 金網素線のピッチ

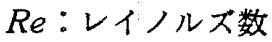

$U:$ 蓄熱体内平均流速

$U_{0}:$ 蓄熱体前平均流速

$\beta:$ 金網の開口比

$\Delta p:$ 差圧

$\varepsilon:$ 空げき率

$\Lambda:$ 無次元長さ
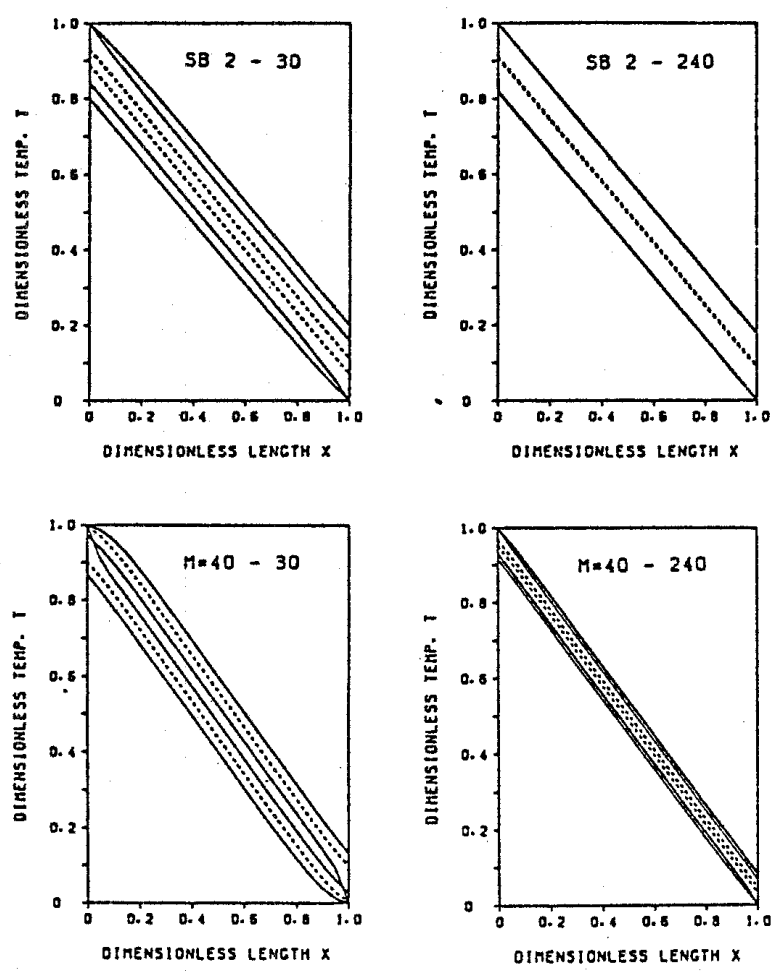

図 1 再生器内温度分布の階差式による計算結果 (実線：空気温度，破線：蓄熱体温度)

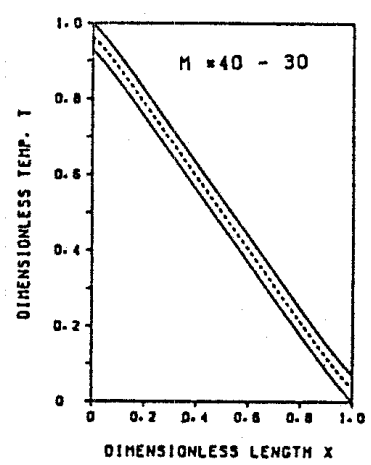

図 $2 \mathrm{M} \#$ 40-30 の場合の再生器内平均温度分布 （実線：受熱㧍よび放熱期間中の平均空気温度, 破線：1サイクル間の平均蓄熱体温度) $\lambda_{a}:$ 空気の熱伝導率

$\nu_{a}:$ 空気の動粘度

$\sigma:$ 比表面積

$\tau:$ 空気流の反転周期

(1) パイプおよびハニカムセラミックス

$R e=U d / \nu_{a}$

$N u=K+\frac{0.104(d / L) \operatorname{Re} \cdot \operatorname{Pr}}{1+0.016[(d / L) \operatorname{Re} \cdot \operatorname{Pr}]^{0.8}}$

壁温一定の場合 $K=3.65$

$$
h=\frac{\lambda_{a} N u}{d}
$$

\section{(2) 鋼球}

$$
\begin{aligned}
& R e=U_{0} d / \nu_{a} \\
& N u=\frac{2+0.75 P r^{1 / 3} \cdot R e^{1 / 2}}{\varepsilon}, \quad h=\frac{\lambda_{a} N u}{d} \\
& \text { (3) ステンレス金網 } \\
& \varepsilon=1-\frac{\pi d \sqrt{p^{2}+d^{2}}}{4 p^{2}}, \quad \beta=(1-d / p)^{2}
\end{aligned}
$$
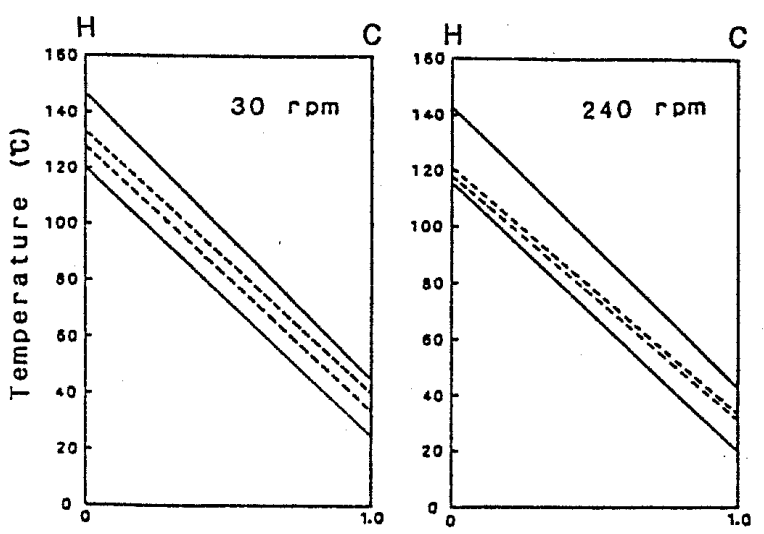

(a) $\mathrm{SB} \phi 2$
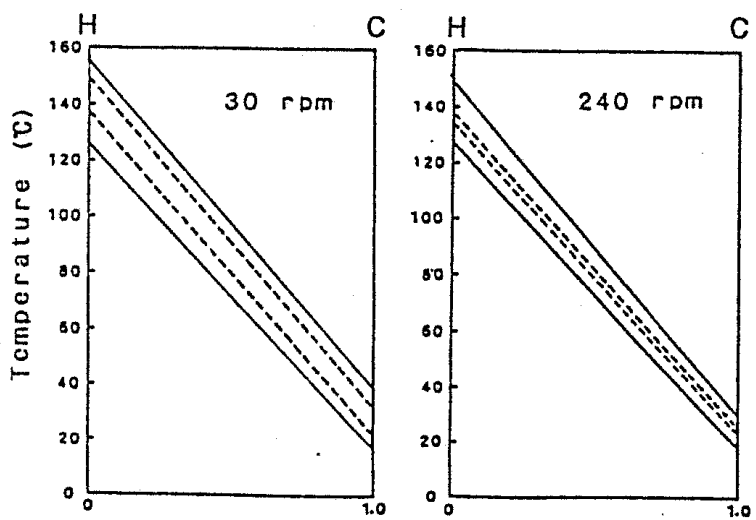

(b) $M=40$

図 3 再生器両端における温度変化

$(H:$ 高温端, $C:$ 低温端, 実線：空気温度, 破線：蓄熱体温度) 


$$
\begin{aligned}
& \sigma=\frac{\pi\left(2 \sqrt{p^{2}+d^{2}}-d\right)}{2 p^{2}} \\
& R e=\frac{U_{0} d}{\beta \nu_{a}}, \quad N u=0.42 R e^{0.56} \\
& h=\frac{\lambda_{a} N u}{d}
\end{aligned}
$$

るに従って，完全に密接して充てんすることが困難と なり，パイプ間のすきまを通る流量が增加してパイプ 外周の熱伝達が無視できなくなるためであると思われ る.

この傾向は P1.9×3にも多少現れている.

（4） 発泡金属, セラミックフォーム

$$
\begin{aligned}
& R e=U_{0} d_{m} / \nu_{a} \\
& N u=0.19 R e^{0.8} \quad(1.5 \leqq R e \leqq 200) \\
& h=\frac{\lambda_{a} N u}{d_{m}}
\end{aligned}
$$

森ら ${ }^{(6)}$ によれば，密接して充てんした細管の場合大 部分の流量は管内を流れ，管外部の流量および熱伝達 は無視しうるとされているので, パイプに対しては （1）に記した管内層流速度助走区間の式を用いた。

ただし伝熱工学資料には壁温一定に対して式中の $K=3.65$ を与えているが, 温度差一定, 熱負荷一定の 場合については述べていない。ここではこの式と並べ て揭載されている速度助走区間の局所層流熱伝達の図 から推定して, 熱負荷一定の場合として, 一応 $K=$ 7.15 の值を採用した。

これらの式によって算出した值と式 (1) から求めた 実験值とを対比した結果を図 4 に示す。

実験値と計算值は全般にかなりよく一致しているけ れども，P3×4では実験值のほうがかなり高い值とな っている。これは第 1 報でも述べたとおり，流入端面

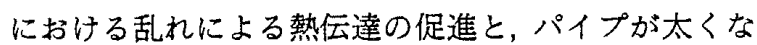

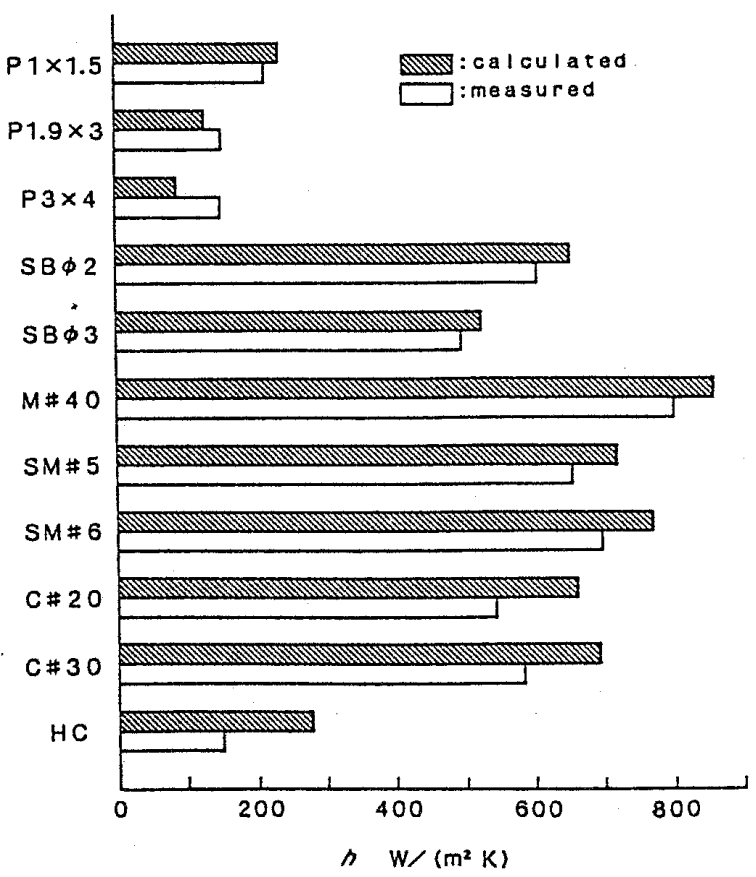

図 4 熱伝達率の計算値と実験值の比較

\section{4. 流 動 抵 抗}

第 1 報で取上げた 11 種の蓄熱体に定常流の室温空 気を流して測定した蓄熱体前後の差圧を図 5 に示す。

図 5 において，パイプおよび八ニカムセラミックス の差圧は流量に対してほ涩直線に近い変化をしてお り,これらの蓄熱体の内部の流れがほほ層流であると して差し支えないことを示している，その他の蓄熱体 の差圧は放物線に近い曲線になっていて, 乱流形の流 動抵抗であることがわかる。

\section{5. 再生器蓄熱体の性能比較}

スターリング機関再生器用蓄熱体の性能としては, 最初に述へたと扔り，（1）伝熱性能，（2）流動抵抗， （3）すきま体積，（4）熱伝導損失の 4 項目にわたって 総合評価する必要がある，そのため, 流動抵抗がパイ

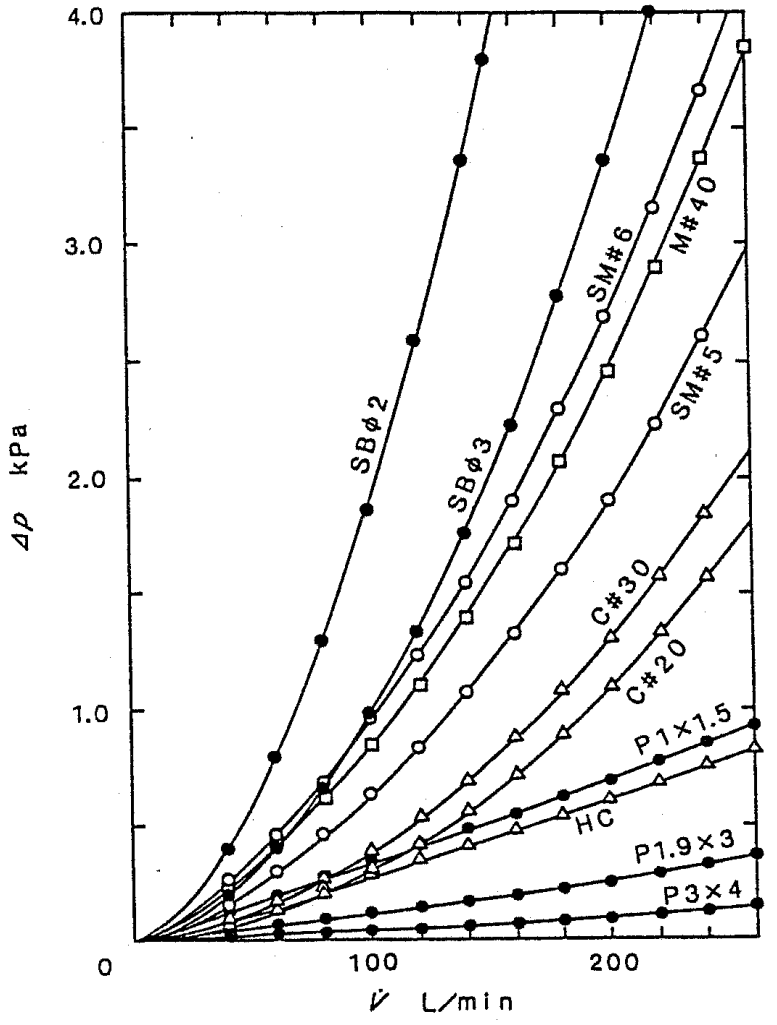

図 5 各蓄熱体の流動抵抗 (Pおよび HCの全長 : $140 \mathrm{~mm}$, その他の蓄熱体の全長： $40 \mathrm{~mm}$ ) 


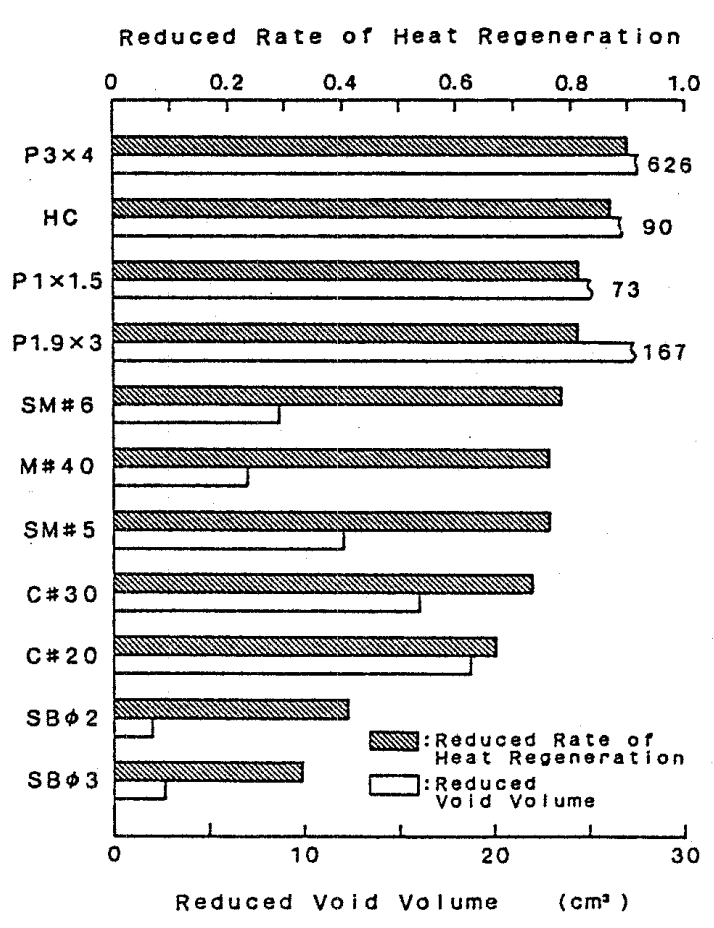

図 6 修正熱再生率と修正すきま体積

プP1×1.5 の抵抗に等しくなるように各蓄熱体の全舆 を修正して，そのときの熱再生率およびすきま体積を 算定して比較することとした，層流形の流動抵抗と乱 流形の流動抵抗の比は流量によって変化するが,ここ

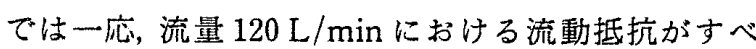
て等しくなるように修正した。

この場合，すきま体積は全長に比例するが，熱再生 率については第 1 報の式（9)を用い，式中の $\Lambda$ が全 長に比例するものとして換算した。このようにして求 めた修正熱再生率および修正すきま体積を図 6 に示 ఫ.

パイプおよび八ニカムセラミックスは修正全長が他 の蓄熱体に比べ非常に長く，修正熱再生率は大きいけ れども，修正すきま体積も非常に大きく，通常のスタ ーリング機関には，このままでは適当ではないと思わ れる。しかし焼却炉の廃熱などを熱源とし，作動ガス として空気または窒素などを用いる場合には，流動抵 抗が機関出力に大きく影響し，一方燃料消費の節隇は さほど重要ではないので，この種の蓄熱体が適当とな ることも考えられる.その場合には全長をいくつかの 区間に分割し，その境界において作動ガス通路を食違
わせるとともに,多少の間隔を置くことによって熱伝 達を促進し，また熱伝導損失の軽隇をはかることが効 果的であると考えられる.

金網 $\mathrm{M} \# 40$ と発泡金属 SM\#6 はほほ同程度の伝 熱性能であるが, 修正すきま体積は金網のほうが少し 小さい、一般に，へリウムまたは水素を作動ガスとす る実際のスターリング機関に用いられている金網は, さらに細かい\#150〜\#200のものが多いので, 発泡金 属を使用する場合にも，さらに目の細かいものを用い ねばならないと思われる。

セラミックフォームは熱再生率, すきま体積ともに 発泡金属よりも少し劣っているが，熱伝導損失が小さ いので，よりいっそう目の細かいものの使用が可能で あれば，かなり有望であると思われる。

鋼球蓄熱体は流動抵抗が大きくて, 再生器用蓄熱体 として適当であるとは思われない.

\section{6. 結 論}

第 1 報においては非定常伝熱実験装置を用いて 11 種の蓄熱体の伝熱性能を測定, 比較したが, 蓄熱体の 両端における空気温度の測定值から熱再生率を算出す るときに立てた仮定の妥当性を，階差式による温度分 布の数值解によって検討し，回転弁の速度 $240 \mathrm{rpm}$ 以 上においては差し支えないことを確かめた。また熱再 生率の算定と同様の方法で求めた熱伝達率の值を, 既 知の実験式で算出した値と比較し，両者の相違につい

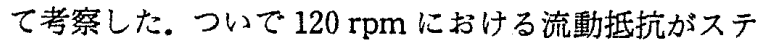
ンレスパイプ $\mathrm{P} 1 \times 1.5$ の抵抗に等しくなるように各蓄 熱体の全長を修正して，その修正全長における修正熱 再生率および修正すきま体積を算定し，それらの值に よって各供試蓄熱体の, スターリング機関再生器用と しての特性および優劣の程度を判定した。

\section{文献}

（1）本論文集 3255 ページ.

（2）泉・児山・新井，機論, 35-276 (1969), 1723.

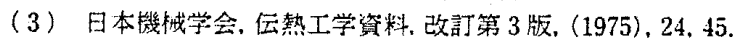

（4）浜口・高㛢・宮部, 機論, 49-445，B (1983)，1991.

(5) 浜口・高挆・宮部, 機論, 49-445, B (1983), 2001.

（6）森・宮崎, 機論, 33-250 (1967), 956.

（7）山下，ほか 4 名、機論, 53-495, B (1987), 3459.

（8）山下， ほ加 10 名，機械技術研究所報告 145, (1988), 74. 